\title{
ensaio
}

\section{A TECNOLOGIA SOCIAL NA PROGRAMAÇÃO DE UM CURRÍCULO CRÍTICO-TRANSFORMADOR NA EDUCAÇÃO EM CIÊNCIAS}

\author{
Miguel Guilhermino de Archanjo Junior ${ }^{1}$ \\ https://orcid.org/0000-0003-3142-436X
}

\author{
Simoni Tormohlen Gehlen ${ }^{2}$ \\ https://orcid.org/0000-0002-9786-3392
}

\section{RESUMO:}

O objetivo da presente pesquisa ${ }^{1}$ consiste em investigar o papel da Tecnologia Social (TS) na apreensão e superação de algumas contradiçôes sociais que constituem um Tema Gerador. Para isso, foi elaborada e implementada uma atividade didático-pedagógica, baseada na TS, em uma comunidade escolar, localizada em Ilhéus-BA, durante um processo formativo de professores da Educação Infantil, com foco na Educação em Ciências. Metodologicamente, a pesquisa compreendeu duas etapas: i) seleção, planejamento e elaboração da atividade baseada na TS; ii) implementação da atividade com as crianças. Dentre os resultados, constatou-se que o processo de Investigação Temática, na obtenção de Temas Geradores, articulado aos fundamentos da TS, como a autonomia e tomada de decisóes, potencializou as ações colaborativas durante o curso de formação de professores, na elaboração das atividades no âmbito da Educação em Ciências. Além disso, foi identificada a autonomia das crianças no enfrentamento das contradições sociais locais, mediante a efetivação das atividades relacionadas aos problemas concretos locais.

\section{LA TECNOLOGÍA SOCIAL EN LA PROGRAMACIÓN DE UN CURRÍCULO CRÍTICO-EMANCIPADOR EN LA EDUCACIÓN EN CIENCIAS}

\section{RESUMEN:}

El objetivo de esta investigación es examinar el papel de la Tecnología Social (TS) en la aprehensión y superación de algunas contradicciones sociales que constituyen un Tema Generador. Para ello, se desarrolló e implementó una actividad didáctico-pedagógica, basada en la TS, en una comunidad escolar, ubicada en Ilhéus-BA, durante un proceso formativo de docentes de Educación Infantil, con enfoque en la Educación en Ciencias. Metodológicamente, la investigación comprendió dos etapas: i) selección, planificación y elaboración de la actividad con base en la TS; ii) implementación de la actividad con los niños. Entre los resultados, se encontró que el proceso de Investigación Temática, en la obtención de Temas Generadores, articulado a los fundamentos de la TS, como la autonomía y la toma de decisiones, potenció las acciones colaborativas durante el curso de formación docente, en la elaboración de actividades en el ámbito de la Educación en Ciencias. Además, se identificó la autonomía de los niños para enfrentar las contradicciones sociales locales, a través de la realización de actividades relacionadas con problemas locales específicos.

Palabras clave: Educación en Ciencias; Tecnología Social; Investigación Temática; Paulo Freire. 


\title{
SOCIAL TECHNOLOGY IN THE PROGRAMMING OF A CRITICAL- TRANSFORMATIVE CURRICULUM IN SCIENCE EDUCATION
}

\begin{abstract}
:
The aim of this research is to investigate the role of Social Technology (TS) in apprehending and overcoming some social contradictions that constitute a Generating Theme. To this end, a didactic-pedagogical activity was developed and implemented, based on the TS, in a school community located in Ilhéus-BA, during a formative process of Early Childhood Education teachers, focusing on Science Education. Methodologically, the research comprised two stages: i) selection, planning and elaboration of the activity based on the TS; ii) implementation of the activity with the children. Among the results, it was found that the Thematic Research process, in obtaining Generating Themes, articulated to the fundamentals of the TS, such as autonomy and decision-making, enhanced the collaborative actions during the teacher training course, in the elaboration of activities in the scope of Science Education. In addition, children's autonomy in dealing with local social contradictions was identified through the realization of activities related to specific local problems.
\end{abstract}

\author{
Keywords: \\ Science Education; Social \\ Technology; Thematic \\ Research; Paulo Freire.
}

\section{INTRODUÇÃO}

Algumas pesquisas na área de Educação em Ciências realizadas no Brasil têm buscado um direcionamento nos pressupostos teórico-metodológicos freireanos, a fim de discutir aspectos relacionados à reestruturação curricular, bem como problematizar contradições sociais, historicamente silenciadas, no sentido de promover uma educação crítica, dialógica e humanizadora (Auler, 2018; Auler e Delizoicov, 2015; Centa e Muenchen, 2016; Delizoicov, 1982, 1991; Milli, Almeida e Gehlen, 2018; Rosa, 2019; Roso, 2017; Roso, Auler e Delizoicov, 2020; Silva, 2004).

A educação emancipadora, pautada em Paulo Freire, propõe a formação de sujeitos críticos, balizada por valores distintos daqueles que os oprimem e os excluem da sociedade, com vista à ruptura de um modelo educacional hegemônico (Auler, 2018). Essa proposta crítico-transformadora busca o desenvolvimento de processos formativos/educativos para a reorientação curricular no Ensino de Ciências e práticas didático-pedagógicas voltadas para a transformação da realidade em que esses sujeitos estão inseridos. É o processo de Investigação Temática (IT), na obtenção e implementação de Temas Geradores, que pode contribuir para desencadear novas concepçôes de mundo, uma vez que as contradições sociais locais possam ser abordadas no ambiente da sala de aula, a fim de compreendê-las e superá-las (Auler e Delizoicov, 2015; Delizoicov e Auler, 2011; Roso e Auler, 2016).

Segundo Auler e Delizoicov (2015), os problemas concretos identificados por meio da IT e representados pelos Temas Geradores podem ser superados por meio do desenvolvimento científico e tecnológico e necessitam ser problematizados no espaço educacional. Os autores também destacam que a transposição desses problemas para o âmbito da educação tem em vista o desenvolvimento de açóes pedagógicas que abarquem as demandas locais/globais vivenciadas pelos educandos, na tentativa de promover a construção de uma consciência crítica e a transformação da sua realidade sócio-histórica. Os Temas Geradores possibilitam identificar as demandas sociais historicamente silenciadas, as quais, são passíveis de tornarem demandas de pesquisa, bem como servir de aporte para elaboração de currículos escolares (Roso, Auler e Delizoicov, 2020). 
Roso e Auler (2016) sinalizam que o processo de IT é de suma importância para a identificação de demandas sociais, e também essas demandas podem ser superadas por meio da Tecnologia Social (TS). Diante disso, os autores explicitam a necessidade de discutir a TS no âmbito educacional como possibilidade de superar os problemas sociais reais de uma comunidade escolar. Roso e Auler (2016) também constataram que são incipientes os estudos que utilizam a perspectiva da TS na Educação em Ciências, culminando em novos desafios para a efetivação de uma proposta educativa emancipadora. Essa ausência de estudos, que também se dá à TS nos processos formativos/educativos, evidencia uma limitação nas discussóes sobre as contradiçóes sociais na elaboração do currículo escolar no Ensino em Ciências, implicando diretamente no desenvolvimento científico-tecnológico, tendo em vista a participação social na comunidade investigada, bem como na promoção de uma reflexão crítica para uma atuação na mesma (Roso e Delizoicov, 2019).

Essas incipiências dão margem para novas discussóes sobre a inserção da TS na Educação em Ciências, principalmente acerca da sua definição, seus fundamentos e possíveis contribuiçôes no processo de ensino-aprendizagem crítico-dialógico. Vale lembrar que a TS é compreendida como uma nova tecnologia para uma sociedade distinta da hegemônica, almejando a superação de um silêncio historicamente reproduzido (suposta neutralidade da atividade científico-tecnológica), ou seja, uma tecnologia que é constituída em produtos, técnicas e/ou metodologias transformadoras reaplicáveis e desenvolvidas com a participação efetiva da comunidade (Dagnino, Brandão e Novaes, 2004). A TS preconiza o desenvolvimento da tecnologia a partir do local, que leva em consideração as necessidades, os objetivos e os interesses de grupos que estão à margem da sociedade, propiciando a sua transformação (Roso e Delizoicov, 2019).

Dagnino (2019) explicita que a forma como a TS tem sido materializada nos últimos 20 (vinte) anos, não corresponde à expressão que tinha sido difundida em sua gênese, havendo assim um deslizamento semântico que possibilitou o uso do conceito dessa tecnologia para designar um significado distinto daquele que foi originalmente atribuído. O autor também ressalta que nas últimas duas décadas constatou-se que os Atores Sociais que atuam nessa concepção de tecnologia são predominantemente acadêmicos e pesquisadores, não contemplando a sociedade civil, implicando assim em agendas de pesquisas que, em muitas vezes, excluem as questóes sociais. Diante disso, Dagnino (2019) propóe reorientar a Política de Ciências e Tecnologia, a partir da Tecnociência Solidária, no sentido de ampliar o conjunto de Atores Sociais nos processos decisórios e potencializar a inclusão social.

O movimento da Tecnociência Solidária tem como primícias postular que o excedente em forma de lucro, seja gerado e distribuído em sua origem, ou seja, nos empreendimentos solidários, potencializando, assim, maior qualidade no equacionamento das demandas sociais que afligem toda sociedade, contribuindo com a inclusão social, como tem sido defendido por Dagnino (2019). O autor também explicita que, para além da mudança de conceito da TS, a efetivação da concepção de Tecnociência Solidária foi necessária problematizar os mitos da neutralidade da Ciência, do determinismo tecnológico e demandas tecnológicas, bem como possibilitou pautar o seu conceito a partir dos fundamentos da TS - aqueles que se aproximam da Economia Solidária. Apesar da dicotomia apresentada entre a TS e Tecnociência Solidária, defende-se no presente trabalho a concepção da TS, uma vez que ela está sendo constituída a partir de distintos Atores Sociais locais (pesquisadores, comunidade escolar e moradores locais), como será explicitado ao decorrer desse trabalho, por meio dos pressupostos teórico-metodológicos freireanos.

Em suma, no presente estudo ${ }^{2}$ a expressão Tecnologia Social (TS) será discutida na perspectiva da Adequação Sociotécnica (democracia sociotécnica), que tem como pressuposto uma concepção de tecnologia voltada para construção social, articulada às questôes valorativas e de interesses coletivos e sociais (Rosa, 2019). Para Dagnino (2014), a Adequação Sociotécnica é compreendida como um processo de reprojetamento dos Atores Sociais, a partir de valores democráticos e interesses coerentes à sua emancipação e inclusão social.

Para Roso (2017), a TS é composta pelos seguintes fundamentos: autonomia, tomada de decisóes, coaprendizagem e reaplicação, que tem como horizonte a transformação social por meio da promoção do protagonismo social. O estudo de Archanjo e Gehlen (2020), ao envolver moradores de uma comunidade 
no processo de reaplicação de uma TS, identificou a autonomia a e coaprendizagem como elementos centrais em uma proposta socioeducacional, em que os Atores Sociais se tornaram protagonistas dos conhecimentos necessários ao desenvolvimento dessa tecnologia. Assim, os autores constaram que esses fundamentos potencializam a inserção da TS em processos educativos que envolvem a comunidade e os seus moradores, bem como fomentam a necessidade de se avançar quanto à inserção da TS na escola, direcionada pelo processo teórico-metodológico da IT (Freire, 1987).

$\mathrm{Na}$ tentativa de ampliar as discussões relacionadas à TS, em uma perspectiva socioeducacional crítico-emancipadora freireana, no âmbito da Educação em Ciências, emergiu o seguinte questionamento: de que forma os fundamentos da TS, orientados pelo processo da IT, podem contribuir para a reorientação curricular e superação de demandas de uma comunidade escolar/local? Nesse sentido, a presente pesquisa tem como objetivo investigar o papel da TS e de seus fundamentos na apreensão e superação de algumas contradições sociais que constituem um Tema Gerador. Esse processo foi realizado no desenvolvimento da IT, durante atividades que envolveram a formação de professores da Educação Infantil, na Escola Padre Giuseppe Bonomi, localizada no município de Ilhéus, estado da Bahia.

\section{A TECNOLOGIA SOCIAL E SUAS RELAÇÕES COM A INVESTIGAÇÃO TEMÁTICA}

Dagnino, Brandão e Novaes (2004) propõem que haja uma reestruturação nas formas associativas e autogestionárias, para que a população que vive à margem da sociedade possa lutar contra o sistema hegemônico (sistema capitalista) que lhe oprime. Auler (2018) explicita que para superar as demandas sociais de uma sociedade subdesenvolvida, faz-se necessário desenvolver uma proposta emancipadora enriquecida de valores alicerçados na participação popular, como solidariedade em equilíbrio com a autonomia individual, os bens sociais de todos, o fortalecimento da democracia pautada nos mecanismos participativos.

Mediante as problemáticas sociais que permeiam as regiões periféricas na sociedade, Roso (2017) afirma que uma possibilidade de equacionar as demandas sociais é por meio do desenvolvimento da TS, de modo que os sujeitos participantes se apropriem de um conhecimento crítico em um processo democrático, o que, por sua vez, potencializa açóes colaborativas em sua comunidade e contribui para superar as contradiçóes sociais vivenciadas. Roso (2017) também menciona alguns exemplos em que a TS foi planejada e implementada com a comunidade de forma dialógica e democrática, como o programa "Um milhão de Cisternas no Semiárido do Nordeste brasileiro," (ASA, 2011) desenvolvido na perspectiva da TS em diversos lugares dessa região, junto à comunidade, com o objetivo de enfrentar uma demanda social/socioambiental do Semi-Árido brasileiro.

Outra característica da TS é a participação colaborativa a ser promovida em diversos espaços sociais, uma ação projetada para potencializar as políticas públicas e democratizar o conhecimento científico, ou seja, uma proposta societária com foco na inclusão social (Lassance Jr. e Pedreira, 2004). Autores como Dagnino, Brandão e Novaes (2004), Dagnino (2011; 2014; 2015), Lassance Jr. e Pedreira (2004), Samagaia (2016), Roso (2017), Auler (2018) e Roso e Delizoicov (2019) também defendem que a TS pode ser efetivada em vários espaços sociais, mas, para isso, é necessário que ela esteja em consonância com os fundamentos que são essenciais em sua implementação, a saber: a autonomia, tomada de decisões, coaprendizagem e a reaplicação - no sentido de potencializar a construção de conhecimentos novos.

Os fundamentos da TS são de suma importância para a democratização do saber em uma proposta societária, propiciando a aquisição de novos conhecimentos aos sujeitos participantes e, também, potencializando o enfrentamento dos problemas concretos que se constituem no seu contexto sócio-histórico (Archanjo e Gehlen, 2020). A interação entre os Atores Sociais pode ser efetivada por meio dos fundamentos da TS, buscando soluções para suas demandas, como explicita Samagaia (2016): 
Nestas novas relaçốes que a comunicação científica se propõe a tecer entre leigos e especialista, a palavra de ordem é a autonomia. Perante o aprendizado das ciências, perante as decisóes cotidianas envolvendo a vida privada dos indivíduos, mas ainda nas resoluções e debates acerca das definições quanto ao futuro comum dos sujeitos. (Samagaia, 2016, p.330).

Para a autora, os conhecimentos populares são constituídos a partir das vivências cotidianas dos sujeitos marginalizados - sujeito leigo/morador local - e os conhecimentos científicos são aqueles provenientes de um processo formativo/educativo e produtivo sistematizado - envolvendo especialistas/técnicos. E, as relações entre esses conhecimentos populares e os conhecimentos científicos, na visão de Samagaia (2016), dão-se por meio da interação entre esses Atores Sociais, a qual potencializa os fundamentos da TS na emancipação dos sujeitos participantes, tornando-os essenciais na reestruturação da prática educativa, bem como no desenvolvimento da sua autonomia em face do protagonismo social.

Tendo em vista os fundamentos da TS, Roso (2017) destaca que a autonomia é constituída a partir de um processo democrático, em que o sujeito tem o seu lugar de fala e participação ativa em uma proposta societária, contribuindo para a formação crítica diante dos problemas presentes em sua realidade. No que se refere ao processo de tomada de decisões, compreende-se que a participação do sujeito não seja de forma tradicional, tampouco, estritamente técnica, isto é, que possibilite uma participação colaborativa e coletiva, em que agregam valores democráticos, éticos e o protagonismo social para formação como um agente multiplicador e transformador, mediante o desenvolvimento na localidade (Lassance Jr. e Pedreira, 2004).

Para Roso (2017), os fundamentos da TS, como a autonomia e tomada de decisôes, são imprescindíveis para o desenvolvimento da coaprendizagem e reaplicação, pois, a partir da autonomia e tomada de decisões, o sujeito se apropria de valores democráticos. Esses valores democráticos possibilitam a superação de ações regidas por um modelo de decisões tecnocráticas, que consiste em uma organização hierarquizada e individualizada, em que o conhecimento está restrito a uma via de mão única, reproduzindo assim, a exclusão social (Dagnino, 2014). Contudo, as atividades que potencializam os fundamentos da TS são capazes de promover a construção do pensamento crítico, colaborando para a efetivação de uma proposta societária.

Além da autonomia, que busca potencializar uma práxis social transformadora nos sujeitos (Rosa, 2019), a coaprendizagem materializa a transformação social por meio de distintos Atores Sociais que compartilham do mesmo problema. A autonomia torna-se essencial para a democratização do conhecimento que permeia a TS, uma vez que esta tecnologia está vinculada à Adequação Sociotécnica. Outro fator a destacar, relacionado à autonomia, refere-se às preposiçôes epistemológicas, que são fundamentais no processo de desenvolvimento da TS, contribuindo para superar a compreensão dos Atores Sociais sobre as problemáticas sociais e socioambientais presentes em suas realidades, bem como efetivar ações colaborativas a partir da integração dos conhecimentos científicos e populares/tradicionais (Auler, 2018; Roso e Delizoicov, 2019).

Auler (2018) também chama atenção para o fato de que a coaprendizagem precede a reaplicação da TS, pois, uma vez que os sujeitos se apropriam dos conhecimentos que permeiam essa tecnologia, possibilita a sua reaplicação para a transformação da sua realidade. Nesse processo societário, leva-se em consideração as especificidades de seus Atores Sociais e os aspectos culturais locais (Rosa, 2019).

Archanjo e Gehlen (2020) sistematizam alguns fundamentos que permeiam a TS e destacam a importância dos sujeitos se apropriarem de Princípios (autonomia e tomada de decisóes) para que possam implementar as Ações (coaprendizagem e reaplicação), isto é, a realização da práxis no seu meio social. Segundo Archanjo e Gehlen (2020), essa proposta societária é desenvolvida com base no processo teórico-metodológico da IT, pautado em Freire (1987), uma vez que tem como horizonte identificar contradiçóes provenientes das relaçôes homens-mundo e discuti-las por meio de uma proposta socioeducacional, na tentativa de superá-las (Archanjo e Gehlen, 2020; Auler, 2018; Rosa, 2019e Roso, 2017). Para Freire (1987), os fatores de opressão limitam as percepçôes dos sujeitos, de modo que não compreendam a realidade em sua totalidade, impossibilitando a humanização dos mesmos. O autor explicita que os sujeitos estão imersos em situaçôes- 
-limites que se apresentam como determinantes históricas, em face das quais adaptam-se e/ou acomodam-se, não lhes restando alternativas para a superação de sua realidade. Neste caso, a TS pode contribuir na construção de uma formação crítica e o empoderamento social do sujeito diante da sua realidade, por meio de açôes societárias coletivas ou individuais na tentativa de transformá-la.

Na busca de uma educação libertadora, Freire (1987) estruturou o processo de Investigação Temática para a obtenção de Temas Geradores, representados pelas contradiçóes sociais presentes na realidade dos sujeitos, e que são passíveis de serem problematizadas e superadas no âmbito educacional. Essa proposta freireana foi sistematizada em cinco etapas para o contexto escolar (Delizoicov, 1982, 1991), quais sejam: 1) Levantamento Preliminar: investigação e reconhecimento local da comunidade; 2) Codificação: análise e escolha de contradiçôes sociais, compreendidas por situaçóes-limites, vivenciadas pelos envolvidos; 3 ) Descodificação: legitimação dessas situações-limite, implicando em possíveis Temas Geradores; 4) Redução Temática: seleção do conteúdo programático para melhor compreender o Tema Gerador e planejamento de atividades didático-pedagógicas, baseadas nos Três Momentos Pedagógicos (3MP); 5) Desenvolvimento em Sala Aula: implementação das atividades em sala de aula. Essa dinâmica também é compreendida no âmbito das Abordagens Temáticas (Magoga e Muenchen, 2020), especificamente a Abordagem Temática Freireana, e tornou-se um subsídio fundamental para organização curricular, assim como tem direcionado práticas pedagógicas voltadas para um Ensino de Ciências emancipador (Garrido e Sangiogo, 2020).

A pedagogia freireana tem em vista a inserção do sujeito em processos de ensino/aprendizagem como um Ser Mais no mundo, capaz de atuar em sua realidade de forma crítica e consciente para a superação das situações-limites (Loureiro e Torres, 2014). Semelhantemente, a TS é uma proposta teórico-metodológica que preconiza a atuação do sujeito como um ser protagonista de sua realidade (Lassance Jr. e Pedreira, 2004). Outros autores têm discutido sobre a importância dessa tecnologia para a disseminação de valores fundamentais na emancipação do sujeito, a exemplo de Dagnino, Brandão e Novaes (2004), ao destacarem que "a proposta da Tecnologia Social, por sua própria natureza, tem como elemento constitutivo o empoderamento e a participação dos usuários na concepção e gestão de instrumentos e metodologias capazes de melhorar suas condiçóes de vida”. (p. 12).

Esses pressupostos que permeiam a TS, aproximam-se da pedagogia libertadora, proposta por Freire e efetivada por meio do processo da Investigação Temática (Freire, 1987), uma vez que a mesma busca desvelar os níveis de percepção dos homens sobre a sua realidade, a fim de trabalhar possíveis Temas Geradores que expressam contradiçôes sociais em que vivem os sujeitos. São essas contradiçôes sociais provenientes de um problema local, historicamente silenciadas, que necessitam ser utilizadas como ponto de partida para desenvolver estratégias capazes de mobilizar os moradores a resolverem as demandas em conjunto. Essas mobilizações desenvolvidas pelos moradores não se restringem apenas ao ato de um "simples fazer", pois elas têm como primícia os processos formativos/educativos e produtivos na perspectiva do cooperativismo, das açôes colaborativas e da autonomia (Rosa, 2019).

Nesse sentido, a relação entre os pressupostos teórico-metodológicos freireanos e a TS apresenta elementos que podem contribuir na ressignificação do currículo para Educação em Ciências, bem como na formação do sujeito capaz de intervir na sua realidade (Archanjo e Gehlen, 2020). Isso porque essas relaçóes podem potencializar os processos formativos/educativos para efetivação de uma educação científica crítico-transformadora, uma vez que esses processos sejam balizados pela dinâmica teórico-metodológica da IT, objetivando a superação das demandas sociais (Rosa, 2019).

A articulação entre o processo da Investigação Temática e a TS, considerando a comunidade escolar e local, é representada na Figura 1 por meio da Organização Cíclica-dialética. 


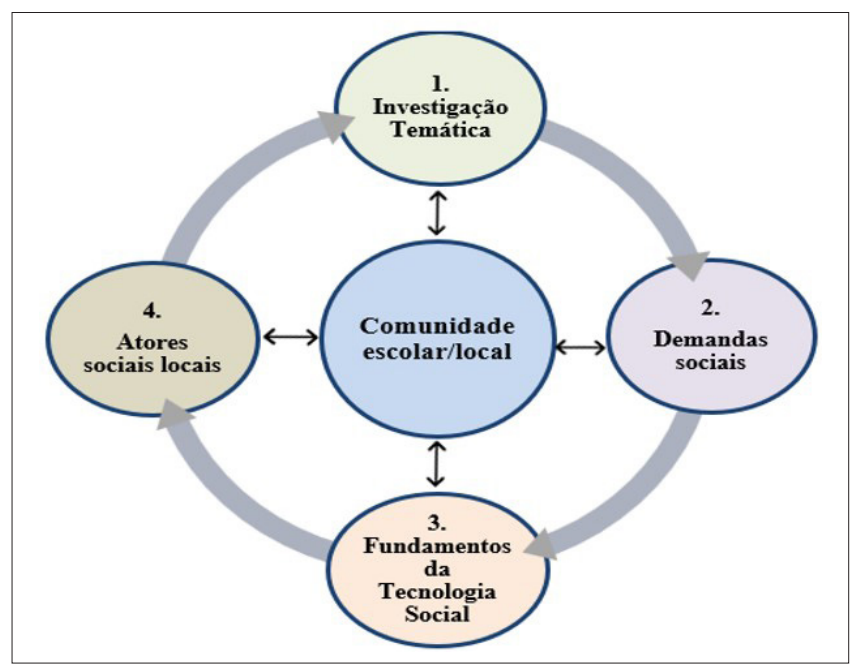

Figura 1. Organização Cíclica-dialética

Fonte: Autores.

Essa Organização Cíclica-dialética (Figura 1) tem no centro a comunidade escolar/local, pelo fato dela compor aspectos como sociais, culturais, históricos, políticos, econômicos, socioambientais, sendo esses, elementos essenciais para a efetivação de uma educação emancipadora, conscientizadora e transformadora. Desse modo, a comunidade escolar/local será foco de investigação por meio do processo da IT em busca da identificação de Demandas sociais (ROSO, 2017), presentes na visão da comunidade. Essas Demandas Sociais podem ser superadas por meio dos Fundamentos da TS (autonomia, tomada de decisóes, coaprendizagem e reaplicação), que potencializam a formação crítica dos seus Atores sociais locais, para que possam auxiliar na construção do protagonismo social e atuar na sua própria transformação. Vale lembrar que os Atores Sociais locais são os sujeitos participantes da prática educativa, como toda a comunidade escolar, os moradores locais, os técnicos, pesquisadores, líderes comunitários e representantes de órgãos públicos competentes.

A Organização Cíclica-dialética é cíclica porque tem como ponto de partida as contradições presentes na comunidade investigada, as quais serão inseridas no âmbito escolar e ressignificadas a partir da dinâmica da ITe os fundamentos da TS, e ponto de chegada à comunidade por meio de práticas societárias. Nesse sentido, a Organização também se constitui como uma perspectiva dialética, uma vez que os conflitos sociais e os fenômenos locais são discutidos em colaboração com os Atores sociais locais. Conforme já destacado, o papel desses Atores Sociais também consiste em ampliar a discussão sobre uma demanda social/socioambiental, a partir de distintas percepções sobre o mesmo problema, pois, possibilita uma atuação ativa de todos os sujeitos envolvidos nesse processo democrático e colaborativo, seja dos especialistas/técnicos ou dos moradores da comunidade local.

No contexto escolar, essa Organização Cíclica-dialética tem um papel fundamental na reorientação curricular e na elaboração de atividades educativas didático-pedagógicas, uma vez que o ponto de partida dessas é a realidade da comunidade local e a compreensão dos Atores sociais locais sobre ela, o que potencializa a formação crítica dos educandos. Essa proposta societária possibilita que esses Atores ajam como protagonistas do saber no âmbito escolar, bem como sejam capazes de atuarem na sua realidade concreta para transformação de sua comunidade, contribuindo na construção da cultura de participação na esfera social que estão inseridos (Rosa, 2019). Isso reforça a relação Cíclico-dialética, representada na Figura 1, uma vez que as Demandas sociais são identificadas na comunidade local e passam a ser problematizadas no contexto escolar, contribuindo para a formação crítica dos educandos e, retornando para a comunidade por meio de ações colaborativas e transformadoras, como a implementação de uma TS (Archanjo e Gehlen, 2020). 


\section{PERCURSOS METODOLÓGICOS}

A presente pesquisa foi desenvolvida no bairro do Iguape, localizado no município de Ilhéus-BA, na Escola Padre Giuseppe Bonomi que é uma instituição filantrópica mantida pela colaboração de recursos da iniciativa privada e instituiçôes religiosas. O bairro do Iguape fica localizado na zona norte do município, região do distrito industrial, formado em área litorânea, com uma grande vegetação de manguezal, banhada pelo Rio Almada. A maioria dos moradores desta área têm a atividade pesqueira como sua principal fonte de renda. O bairro apresenta vários problemas sociais, como a deficiência no saneamento básico, com o descarte de resíduos e dejetos domésticos no manguezal e as inundaçôes nas ruas, devido à ausência de redes pluviais, impactando na contaminação do solo, da água (do rio e do mar) e do manguezal, que podem causar diversos problemas de saúde pública na localidade (Assunção, 2019).

$\mathrm{Na}$ tentativa de compreender as demandas da comunidade e abordá-las no espaço escolar, o Grupo de Estudos em Abordagem Temática no Ensino de Ciências (GEATEC ${ }^{3}$ em colaboração com 8 (oito) professoras e a coordenadora pedagógica da Escola Padre Giuseppe Bonomi, desenvolveram o processo formativo "O Brincar no contexto dos Três Momentos Pedagógicos”, com a carga horária de 40 horas, no período de março a novembro de 2018. O objetivo deste processo consistiu em organizar a programação curricular da Educação Infantil, elaborar e implementar atividades didático-pedagógicas, tendo como referência o Tema Gerador " $A s$ riquezas naturais do Iguape: entre o discurso e a prática” (Assunção, 2019). Dentre essas atividades, destacam-se aquelas que contemplam aspectos da TS, que foram sistematizadas a partir de duas etapas:

i) Seleção, planejamento e elaboração da atividade baseada na TS: a seleção da TS foi realizada tendo como critério as demandas socioambientais da comunidade do Iguape, como o descarte irregular de dejetos domésticos no bairro, em especial na própria escola (Archanjo, 2019). Esse problema também foi considerado pelos moradores do bairro, que construíram uma Fossa Séptica Ecológica, atendendo alguns Princípios e Açóes da TS (Archanjo e Gehlen, 2020), para solucionar o descarte irregular de dejetos na escola. Dada a importância dessa TS, as professoras decidiram abordar alguns aspectos da construção e funcionamento da Fossa Séptica Ecológica na elaboração das atividades com as crianças, cujos conhecimentos estavam relacionados ao tratamento da água. Essas atividades foram sistematizadas seguindo a dinâmica dos $3 \mathrm{MP}$, denominada de "Construindo uma fossa" (Quadro 2), em que foram realizadas problematização relacionadas aos problemas de saneamento básico local e o desenvolvimento de algumas atividades educativas para discutir possíveis soluçôes para esta demanda local. Para isso, as professoras elaboraram algumas atividades sobre a Fossa Séptica Ecológica, inclusive realizaram com as crianças a montagem de uma réplica com materiais recicláveis. Do ponto de vista da TS, essa atividade foi planejada tendo como ponto de partida as demandas sociais e socioambientais identificadas e legitimadas por meio do processo de IT, que configuram a realidade da comunidade do Iguape. Nesse processo de identificação e legitimação das demandas sociais, constatou-se as demandas tecnológicas, que foi a necessidade da Fossa Séptica Ecológica como meio para superá-las, pautando no processo de Adequação Sociotécnica, no sentido de buscar democratizar a participação de distintos Atores Sociais para a superação das demandas locais, mediante a proposta didático-pedagógica estabelecida. O processo de Adequação Sociotécnica, nesse contexto, torna-se um componente fundamental para a superação da problemática local, uma vez que demanda uma dimensão tecnológica na perspectiva da TS (Thomas, 2009).

ii) Implementação da atividade com as crianças: a atividade "Construindo uma fossa” foi implementada em uma turma com 18 (dezoito) crianças, da pré-escola, na Escola Padre Giuseppe Bonomi, com duração de 4 (quatro) horas. A escolha desta turma deu-se em função da professora, responsável por esta turma, ter participado ativamente de todos os encontros do presente processo formativo. Discutiu-se com as professoras que as demandas sociais locais são passíveis de serem superadas por meio 
das demandas tecnológicas, desde que levem em consideração o processo de Adequação Sociotécnica, ou seja, os valores democráticos presentes na participação de seus Atores Sociais. É importante lembrar que a reaplicação da Fossa Séptica Ecológica pelos moradores da comunidade (Archanjo e Gehlen, 2020) atendeu a compreensão de Thomas (2009) sobre a TS, que destaca a importância de se "implementar e administrar tecnologia orientada a resolver problemas sociais e ambientais, gerando dinâmicas sociais e econômicas de inclusão social e de desenvolvimento sustentável" (Thomas, 2009, p.27). Para além disso, a Fossa Séptica Ecológica busca efetivar a equidade a partir da formação crítica de seus participantes, com a finalidade de torná-los agentes transformadores de suas realidades e, assim, formar uma sociedade organizada a partir valores contra-hegemônicos.

As informações foram obtidas por meio de videogravações tanto na etapa do planejamento da atividade durante o processo formativo - quanto no desenvolvimento dela com as crianças. Também foram utilizadas algumas falas das professoras obtidas de uma entrevista realizada, nesse processo formativo, por Santos et al. (2019), em que elas explicam aspectos relacionados à Rede Temática. Vale destacar que, essas professoras que participaram da entrevista, serão identificadas por Prof.E1, Prof.E2 e Prof.E3. Na presente pesquisa, foram consideradas também as falas de três professoras que participaram assiduamente do processo formativo, identificadas por Prof1, Prof2 e Prof3. As falas das professoras da entrevista realizada por Santos et al. (2019) foram identificadas com o índice E, por exemplo, ProfE1. As crianças foram representadas por: Cri1, Cri2...Crin, e integrantes do GEATEC foram identificados como Pq1, Pq2 e Pq3, com o objetivo de garantir a privacidade de todos os envolvidos.

A análise dessas informaçôes foi realizada por meio da Análise Textual Discursiva (Moraes e Galiazzi, 2011), que no presente estudo correspondeu as seguintes etapas: a) unidades de significado: foram constituídas a partir das falas das professoras e das crianças durante a seleção e implementação da atividade didático-pedagógica, que apresentaram alguns elementos relacionados aos fundamentos da TS; b) categorização: agrupam-se as unidades de significado, de acordo com semelhanças semânticas das falas, tendo como referência duas categorias a priori, baseadas em alguns fundamentos da TS, como a autonomia e a tomada de decisóes (Roso, 2017), quais sejam: i) Autonomia na elaboração do currículo e das atividades e; ii) Tomada de decisóes na elaboração e implementação da atividade de Ciências Naturais; c) metatexto: elaboraram-se os metatextos, originados a partir das interpretaçóes e descriçôes baseadas nas unidades de significados e nas referidas categorias. Buscou-se o novo e emergente, ou seja, a identificação de novos valores, diferentes dos presentes na sociedade hegemônicas.

\section{APRESENTAÇÃO E DISCUSSÃO DOS RESULTADOS}

No processo formativo desenvolvido no estudo de Assunção (2019) foi obtido em conjunto com os integrantes do GEATEC e as professoras da Escola Padre Giuseppe Bonomi, o Tema Gerador "As riquezas do Iguape: entre o discurso e a prática” e elaborou-se uma Rede Temática, o Ciclo Temático e as Unidades de Ensino. É importante apresentar, aqui, uma síntese desse processo de construção, uma vez que ele tem papel essencial na seleção, elaboração e desenvolvimento de atividades didático-pedagógicas para as crianças, envolvendo a TS. Além disso, essas atividades são realizadas em continuidade ao estudo Assunção (2019), que teve como foco a elaboração do Projeto Político-Pedagógico da Escola Padre Giuseppe Bonomi, incluindo a sistematização da Programação Curricular.

A Rede ${ }^{5}$ Temática (RT) - elaborada após a seleção do Tema Gerador - além de apresentar a visão de mundo da comunidade e dos educadores, também se constitui em um processo de seleção de TS, ou seja, representa demandas sociais, passíveis de serem superadas e essenciais para serem trabalhadas na comunidade escolar. A exemplo disso foi a construção da Fossa Séptica Ecológica com os moradores do bairro do Iguape, em que houve a reaplicação desta TS na própria escola (Archanjo e Gehlen, 2020). As demandas sociais e socioambientais presentes na RT, podem ser superadas por meio da TS, ou seja, uma demanda tecnológica contra-hegemônica, configurando, assim, o desenvolvimento de um processo de Adequação Sociotécnica com a finalidade de su- 
perar os problemas locais, bem como potencializar a integração dos distintos Atores Sociais, democratizar o conhecimento científico e valorizar os conhecimentos populares/tradicionais (Dagnino, 2019).

Para que fosse possível desenvolver essas atividades na escola com as crianças, elaborou-se com os integrantes do GEATEC e as professoras as Unidades de Conhecimento, tendo como referência o Ciclo Temático (Assunção, 2019), quais sejam: i) Poluição das águas; ii) Pesca e iii) Manguezal, como ilustra o Quadro 1.

\section{Quadro 1. Unidades de Conhecimento das Ciências Naturais}

\begin{tabular}{|c|c|c|c|}
\hline Unidade I & Unidade II & \multicolumn{2}{|c|}{ Unidade III } \\
\hline Poluição das Águas & Pesca & \multicolumn{2}{|c|}{ Manguezal } \\
\hline \multirow{2}{*}{$\begin{array}{l}\text { Resíduos domésticos no manguezal } \\
\text { e no rio; } \\
\text { Fossas; } \\
\text { Doenças: contaminação dos animais e } \\
\text { dos alimentos; } \\
\text { Tratamento de água: EMBASA/filtros } \\
\text { de água; } \\
\text { Rede de esgoto; } \\
\text { Políticas Públicas. }\end{array}$} & \multirow[b]{2}{*}{$\begin{array}{l}\text { Tipos de pesca; } \\
\text { Instrumentos de pesca; } \\
\text { Marés: Fases da Lua; } \\
\text { Tipos de peixes e mariscos; } \\
\text { Pesca predatória; } \\
\text { Aspectos históricos; } \\
\text { Preservação; } \\
\text { Conscientização; } \\
\text { Cultura de subsistência; } \\
\text { Fiscalização. }\end{array}$} & Subunidade & $\begin{array}{l}\text { Ecossistemas: } \\
\text { Biodiversidade }\end{array}$ \\
\hline & & \multicolumn{2}{|c|}{$\begin{array}{l}\text { Diferença entre mangue e manguezal; } \\
\text { Poluição do manguezal; } \\
\text { Desvalorização da cultura local; } \\
\text { Descaso da população; } \\
\text { Resgate histórico das riquezas } \\
\text { naturais do bairro; } \\
\text { Preservação do manguezal; } \\
\text { Cultura de subsistência; } \\
\text { Importância econômica. }\end{array}$} \\
\hline \multicolumn{4}{|c|}{ Falas de moradores } \\
\hline $\begin{array}{l}\text { M1- Limpo num é né, até porque tem } \\
\text { muito esgoto num é? Prejudica os } \\
\text { peixes, prejudica as crianças né, atrai } \\
\text { muito..., mas, pra mim tá de boa. } \\
\text { M3- Pra mim não atrapalha não, até } \\
\text { ajuda por que agora mermo com esse } \\
\text { negoço da água, até água agente pegou } \\
\text { lá pra jogar no vaso sanitário, porque } \\
\text { tinha oito dia sem água né...Agora o } \\
\text { saneamento básico que é ruim porque } \\
\text { não tem o esgoto, aqui não passa, aí caí } \\
\text { lá (se referindo ao mangue). }\end{array}$ & $\begin{array}{l}\text { M2- Então, ainda essa semana a } \\
\text { gente foi pescar. A gente vai sempre } \\
\text { pescar camarão, e a gente outro } \\
\text { dia estava pensando: de onde tira } \\
\text { o próprio alimento e o pessoal tem } \\
\text { coragem de jogar lixo, esgoto... } \\
\text { M4- [..] muitas pessoas que não } \\
\text { tem condições né, de sobreviver e } \\
\text { vai lá né, pegar o pão de cada dia. } \\
\text { Eu mesmo, por exemplo, agora Deus } \\
\text { abriu uma porta pra mim, e eu não } \\
\text { preciso de tá no mangue. Mas, de vez } \\
\text { em quando também eu vou né, mas } \\
\text { tem muitas pessoas que convive do } \\
\text { mangue né? Que é área de pesca } \\
\text { também né? É. Entendeu né? Os } \\
\text { marisqueiros se vira como pode (sic). }\end{array}$ & $\begin{array}{l}\text { M6- Eu acho } \\
\text { mas acabar } \\
\text { também fica d } \\
\text { Pesq.: Mas s } \\
\text { sentido? Tirar } \\
\text { é ruim? } \\
\text { M6- Se conta } \\
\text { estão se alime } \\
\text { Ag- [..] a maio } \\
\text { rio é poluído, } \\
\text { rio deveria se } \\
\text { comunidade } \\
\text { deveria ser tra } \\
\text { todo detrito se } \\
\text { a água é poluíc } \\
\text { banho, os peix } \\
\text { e até nós m } \\
\text { esses peixes, } \\
\text { doença, isso po } \\
\text { né? Que não va }\end{array}$ & $\begin{array}{l}\text { que seria melhor né, } \\
\text { om toda vegetação } \\
\text { ícil, né? } \\
\text { ria melhor em que } \\
\text { mangue? o mangue } \\
\text { ina as pessoas, que } \\
\text { tando infelizmente. } \\
\text { ia aqui já sabe que o } \\
\text { ão toma banho. Esse } \\
\text { mais tratado, mas a } \\
\text { o ajuda. Essa água } \\
\text { da, mas não é, então } \\
\text { joga no rio e por isso } \\
\text { a, aí o povo não toma } \\
\text { s são contaminados, } \\
\text { smo que comemos } \\
\text { podemos pegar uma } \\
\text { falta do poder público } \\
\text { oriza, não trabalha. }\end{array}$ \\
\hline
\end{tabular}

Fonte: Extraído de Assunção (2019, p.110).

Nessas Unidades pode-se identificar diversos conteúdos em que é possível explorar aspectos da TS, em sala de aula. Por exemplo, algumas atividades didático-pedagógicas de Ciências Naturais podem envolver a pesca e o cultivo de mariscos, que são atividades econômicas comuns no bairro Iguape. Ou seja, as relaçôes ecológicas entre os animais endêmicos locais, os aspectos socioambientais no que se refere à pesca predatória e a contaminação da água e do solo, bem como a prevenção e possíveis tratamentos de doenças infecciosas, por conta dos dejetos domésticos. Isso, aliado ao fato de que os moradores do bairro do Iguape terem considerado a necessidade da construção de uma Fossa Séptica Ecológica, no sentido de solucionar ou amenizar o problema do despejo dos dejetos domésticos no manguezal local (Archanjo e Gehlen, 2020). 
As compreensões dos moradores do bairro do Iguape, sobre a questão do despejo dos dejetos domésticos no mangue, bem como suas alternativas sobre a resolução deste problema, por meio de uma TS (Archanjo e Gehlen, 2020), direcionaram o planejamento e desenvolvimento da atividade didático-pedagógica relacionada à Fossa Séptica Ecológica. Essa atividade ${ }^{6}$ foi organizada seguindo a dinâmica dos $3 \mathrm{MP}$ e desenvolvida com as crianças, tal como apresenta o Quadro 2.

\section{Quadro 2. Atividade "Construindo uma fossa", baseada nos 3MP}

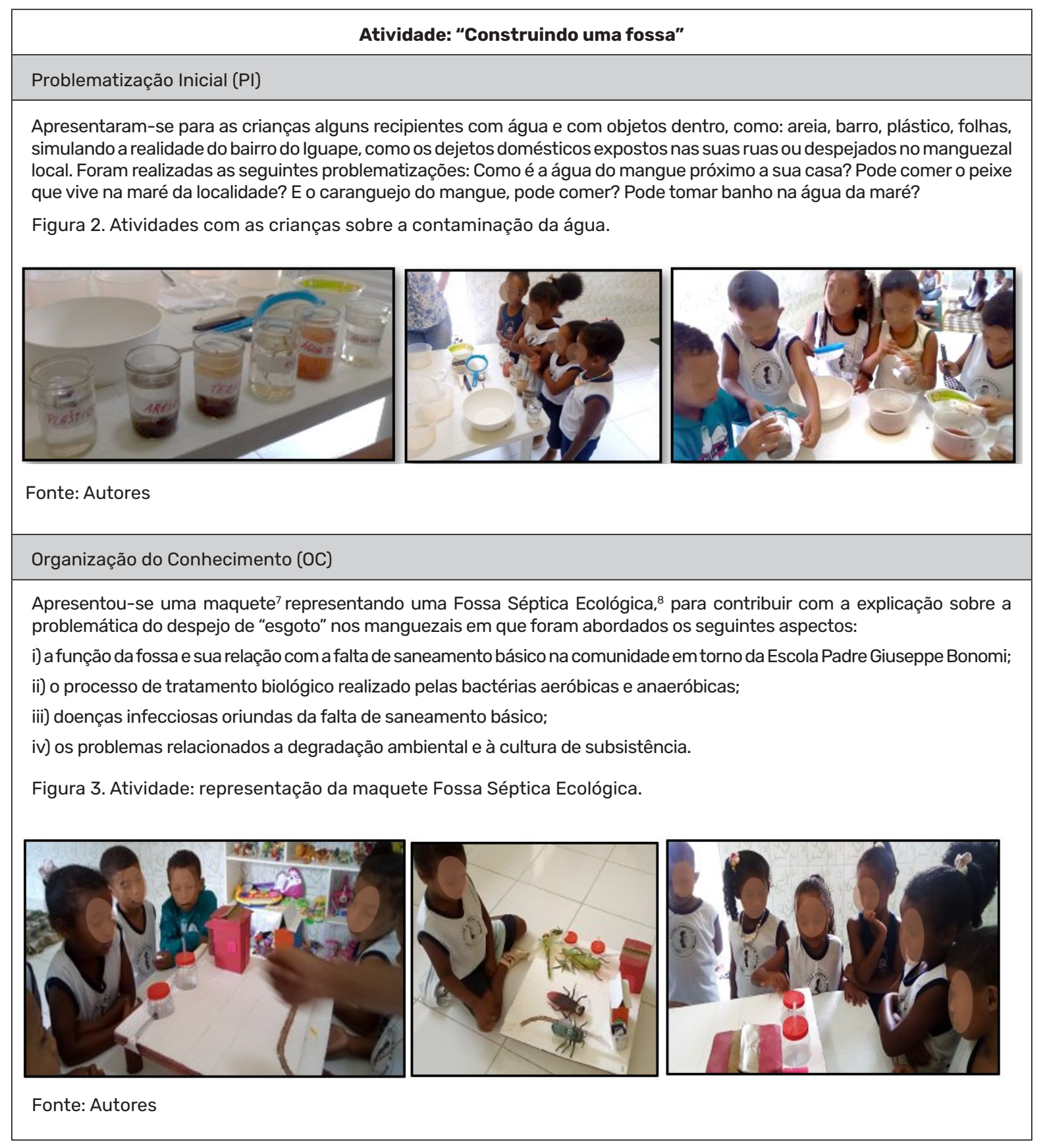


Aplicação do Conhecimento (AC)

Retomada de algumas questões da PI sobre as demandas locais, como aquelas envolvendo o descarte de dejetos domésticos no manguezal, no rio e nas ruas da comunidade. As crianças foram desafiadas a identificarem na maquete os locais em que ocorrem o descarte irregular dos dejetos domésticos e colocar alguns animais, como baratas, ratos, gafanhotos e libélulas, de acordo com o ambiente poluído ou ambiente onde ocorre o tratamento dos dejetos por meio da fossa.

Figura 4. Reconhecendo o tratamento dos dejetos domésticos na maquete Fossa Séptica Ecológica.
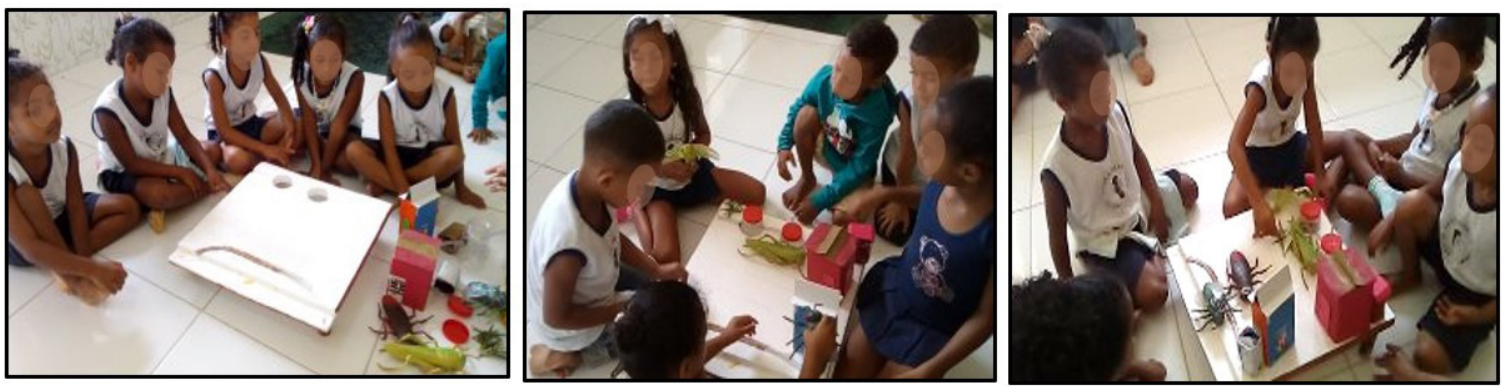

Fonte: Autores

\section{AUTONOMIA NA ELABORAÇÃO DO CURRÍCULO E DAS ATIVIDADES}

A autonomia dos Atores Sociais, diante de uma proposta socioeducacional, tem sido discutida por diversos atores, como Rosa (2019), Auler (2018), Roso (2017), na tentativa de promover uma educação emancipadora. Para Freire (2013), a autonomia do sujeito pode se dar por meio de uma prática educativa crítica, no sentido de propiciar condições das suas relações uns com os outros, sem a influência de uma autoridade externa, assumindo-se como ser social, histórico, dialógico e transformador.

Vale destacar as falas de algumas professoras, que participaram do processo formativo/educativo na Escola Padre Giuseppe Bonomi, que explicitaram suas compreensões em relação à participação na elaboração da RT e a sua relevância na construção do conhecimento crítico. A exemplo da Prof1 ao explicar que:

[...] (A Rede Temática) revela a capacidade de aproximar o contexto com o conbecimento científico. Ai a rede acaba fazendo o quê? Estabelecendo uma ponte entre essas visóes da comunidade e do professor na construção desse saber. É no meio do diálogo que encontram os conteúdos de cada área do conbecimento, que possam ser selecionados e aplicados na hora de preparar as aulas. (Prof.E1- Grifo nosso).

Primeiro ela (a Rede Temática) melhora, causa melhor interação entre o professor e a comunidade na hora de selecionar os conteúdos. Causa também o envolvimento dos professores nesse processo, de modo que ele passa a perceber quais são os problemas da comunidade, identifica, reconbece e, a partir dali, ele vai começar a trabalhar, a preparar a aula, partindo desse pressuposto. (Prof.E1 - Grifo nosso).

A fala da professora Prof1 revela uma compreensão sobre a RT, em especial sobre a capacidade que ela tem para aproximar o conhecimento científico e a visão da comunidade. Essa aproximação evidencia a internalização de valores que buscam alcançar transformações socioeducacionais por meio de uma proposta didático-pedagógica vinculada à realidade local (Rosa, 2020). Nessa relação, em que a necessidade pelo conhecimento científico emerge da discussão e compreensão sobre o meio social local, de forma interdisciplinar e democrática, potencializa uma educação emancipadora, regida pela dialogicidade e a consciência crítica de seus participantes (Atores Sociais), o que está em coerência com os pressupostos freireanos (Freire, 1987). Também é possível perceber na fala da Prof 1 a superação de visões ingênuas de mundo, propiciando a construção de uma consciência crítica da realidade potencializando ações transformadoras sobre as contradiçôes 
vivenciadas pela comunidade escolar, ou seja, são manifestações e concepções essenciais na superação dos Obstáculos Gnosiológicos, a exemplo do medo da liberdade 9 (Alves e Silva, 2015).

Essa superação do medo da liberdade, identificada na compreensão da Prof1, consiste na construção de uma visão acrítica com relação a elaboração e implementação de um currículo crítico-reflexivo no Ensino de Ciências, capaz de promover a emancipação do sujeito (Silva, 2004). A Prof1, ao apontar o processo formativo/educativo em uma perspectiva dialógica e colaborativa, como possível caminho na organização de um currículo crítico-reflexivo e a elaboração de atividades a partir da realidade da comunidade escolar local, evidencia aspectos da autonomia, como o pluralismo, igualdade participativa, princípios da inclusão, bem-comum, tornando-se imprescindíveis para a promoção de uma educação libertadora (Rosa, 2019). Nesse sentido, pode-se identificar alguns avanços das professoras com relação ao entendimento sobre a RT e suas possíveis contribuiçôes no processo educativo, como fica evidente na fala de Prof2:

Como educadora en acho importante aderir a Rede Temática à prática pedagógica, porque a partir daquela realidade local da escola, da comunidade, o aluno vai se sentir presente, pertencente daquilo que vai ser exposto na sala de aula. Ele vai ver que o que está sendo tratado em sala de aula, náo éalgo que está distante dele. Pelo contrário, é algo que está muito próximo, que está inserido na vida dele. (Prof.E2, Grifo nosso).

Prof 2 compreende que a adesão da RT no planejamento de açốes educativas pode contribuir no desenvolvimento de pertencimento dos educandos, uma vez que serão trabalhados em sala de aula, conteúdos relacionados às problemáticas locais, que estão diretamente relacionados às suas vivências, contribuindo assim, para uma compreensão mais ampla e crítica da sua realidade. Também é possível evidenciar na fala de Prof2 uma percepção crítico-reflexiva a partir das falas significativas representadas na RT, que denunciam as contradições sociais locais, a fim de problematizá-las e abordá-las no espaço escolar, por meio de um engajamento em trabalhos colaborativos, enriquecidos de valores democráticos (Silva, 2004). Para Rosa (2019), esses são elementos essenciais para a construção da autonomia dos educadores e dos educandos, mediante um processo formativo/educativo. Desse modo, o processo formativo/educativo pautado na ética libertadora, problematização do cotidiano pedagógico, busca reorganizar o currículo escolar a partir da realidade denunciada na RT e anunciar ações transformadoras entre os distintos sujeitos comunitários, como é explicitado por Silva (2004). Além disso, esse o processo formativo/educativo articulado entre a comunidade acadêmica, comunidade escolar e comunidade local, como tem sido discutido por Archanjo e Gehlen (2020), a partir da relação da IT e TS, também pode contribuir para formar Atores Sociais construtores de uma sociedade autônoma. O que chama atenção aqui é que o anúncio possibilitará transformar os problemas locais em conteúdos programáticos na sala de aula, a partir da relação dialógica, na perspectiva freireana, como foram sinalizados por Prof1 e Prof2.

Pressupóe-se que a aprendizagem na perspectiva dialógica a partir da relação entre a IT e a TS consiste em conceber demandas sociais locais no processos científico-tecnológicos e produtivos, visando a sua superação, estando em consonância com os fundamentos da TS, como a autonomia (Roso, 2017). A prática educativa societária enriquecida pelos valores democráticos como a autonomia, interação, entre outros, podem contribuir para uma sociedade diferente da hegemônica (Archanjo e Gehlen, 2020). Outros aspectos sobre a autonomia podem ser identificados na fala da Prof2, mediante o processo formativo/educativo, ao explicitar:

Como se trata da Rede Temática, da relevância, da importância dela na organização curricular, a gente percebe que ela acaba se tornando valiosissima. Ela nos traz a possibilidade de fazer uma leitura coletiva da realidade onde a escola está inserida, traz detalhadamente os discursos da comunidade relacionando determinados assuntos onde a gente pode construir um diálogo trazendo uma concepção tanto metodológica quanto epistemológica para que haja uma prática educativa efetiva. (Prof.E2 - Grifo nosso).

A concepção de Prof2, com relação a RT, explicita a contribuição na reorientação curricular, além de promover atividades didático-pedagógicas interdisciplinares, colaborativas e democráticas, tendo como 
ponto de partida o meio social local. A partir da fala de Prof2, constata-se que os aspectos sociais presentes na comunidade se tornam elementos fundamentais para uma educação crítica, dialógica e transformadora, uma vez que eles sejam problematizados em processos decisórios e democráticos juntos aos seus Atores Sociais. Essa relação dialógica potencializa a autonomia das professoras na organização curricular, bem como na prática educativa, pois há uma participação colaborativa e efetiva entre os seus pares.

Além disso, o desenvolvimento de atividades pautadas na realidade dos educandos, torna-se substancial para formação de cidadão construtor de uma sociedade mais igualitária, autônoma, inclusiva e democrática, que estão em sintonia com a proposta da TS (Roso, 2017). Para Freire (2013), a autonomia no espaço educativo se dá a partir da autorreflexão crítica e dialogicidade, no sentido de compreender, quanto sujeitos sócio-histórico-culturais, o meio em que estão imersos e lutar pela sua transformação a partir de uma educação emancipadora, ou "uma prática educativa efetiva", como propóe a Prof2. Dessa forma, a Prof2 aponta que a RT potencializa a democratização do conhecimento científico de maneira colaborativa, e possibilita que os professores envolvidos nesse processo formativo/educativo desenvolvam autonomia e o pensamento crítico, com relação às demandas presentes no contexto social local.

Após a reorientação do currículo da área de Ciências Naturais e o planejamento das atividades didático-pedagógicas no processo formativo/educativo, no espaço escolar da Escola Padre Giuseppe Bonomi, as atividades foram implementadas e, mediante suas efetivaçôes, a Prof3 sinalizou alguns aspectos que se aproximam da autonomia dos educandos com relação aos seus problemas vivenciados, como apresenta:

\begin{abstract}
Algumas crianças passaram a ter uma linguagem mudada, tipo o lixo não joga mais no lixo, mas sim na lixeira. O lixo passa a ser resíduos, muitos mudaram essa concep̧̧ão. Ealém de tudo saber que o lixo nem sempre é lixo, eles tiveram essa consciência de aprender o sentido da palavra. E a questão da água também, que nem toda água é limpa, às vezes ela pode com a aparência limpa e eles sabem disso, têm consciência disso. (Prof3).
\end{abstract}

A fala de Prof3 evidencia a apropriação de conhecimentos significativos presentes na implementação de atividades didático-pedagógicas de Ciências com as crianças, configurando o espaço educacional como um ambiente importante na formação crítica e construção da autonomia dos sujeitos, uma vez que o currículo escolar contemple elementos culturais, políticos e sócio-históricos da comunidade investigada e, a sua implementação esteja pautado na problematização, dialogicidade e conscientização (Silva, 2004). Esses aspectos presentes na fala de Prof3 potencializam açóes cada vez mais democráticas e participativas no âmbito educacional, em que os seus autores sociais são sujeitos ativos em todas as etapas do processo formativa/ educativo, aproximando-se dos fundamentos da TS (Dagnino, 2015).

Além de constatar na fala de Prof3 a relevância de discutir os problemas da comunidade em sala de aula, identificou-se uma prática docente autônoma nos seguintes aspectos: a visão crítica da professora sobre a percepção das crianças, o processo dialógico nessa interação e a contextualização das atividades propostas com a realidade da comunidade escolar. Esses aspectos estão em coerência com a proposta freireana, bem como se aproximam dos fundamentos da TS, em especial a autonomia, que se dá por meio de um processo colaborativo e dialógico (Roso, 2017).

Ao pensar a formação docente e a prática educativa, direcionadas por valores distintos dos hegemônicos, é necessário levar em consideração as dimensôes decisórias, histórica e sociocultural dos Atores Sociais envolvidos na elaboração curricular, de forma que contribua amplamente para a discussão e construção da cultura de participação no âmbito educacional (Rosa, 2019). Desse modo, a potencialização da autonomia nos Atores Sociais, por meio de ações educativas crítico-reflexivas, contribui no enfrentamento de problemas concretos presentes em sua realidade. 


\section{TOMADA DE DECISÕES NA ELABORAÇÃO E IMPLEMENTAÇÃO DE ATIVIDADES DE CIÊNCIAS}

No desenvolvimento do processo formativo/educativo, em que são planejadas e implementadas as atividades didático-pedagógicas que envolvem conhecimentos da área de Ciências Naturais, na perspectiva das brincadeiras, foi possível identificar aspectos relacionados aos processos decisórios (Roso, Auler e Delizoicov, 2020), uma vez que a autonomia potencializa os processos de tomada de decisóes na perspectiva da TS, de formas não tradicionais ou estritamente técnicas (verticalizada, segmentada e excludente), mas em atos educativos coletivos, debatidos e, então, as decisóes são tomadas. Um exemplo disso pode ser observado quando o pesquisador Pesq1, questiona a Prof4:

As brincadeiras, planejadas e implementadas entre vocês professoras e os integrantes do GEATEC, são diferentes das brincadeiras que vocês têm desenvolvido aqui na escola? Se sim, de que maneira?(Pesq1).

Sim, pois dificilmente usamos jogos de tabuleiro. Todas as brincadeiras foram tiradas de um diagnóstico em sala, através de conversas com eles e dai foram criadas brincadeiras para conscientizar, para eles passarem a ser diferentes, terem atitudes diferentes daquelas que eles já tinham. (Prof4).

No entender de Prof4, a valorização do contexto histórico da comunidade local na elaboração de atividades didático-pedagógicas se deu por meio de "conversas com eles (pesquisadores)", ou seja, ações participativas, colaborativas, o que evidencia um processo democrático na tomada de decisões (Roso, 2017; Auler e Delizoicov, 2020). Além disso, constatou-se na fala de Prof3 que a tomada de decisões não é centralizada pelos integrantes do GEATEC, mas, sim, tomada pelo coletivo, tendo como horizonte a socialização dos conhecimentos científicos no processo formativo/educativo, tornando-se elementos que podem contribuir para o posterior desenvolvimento da TS (Roso, 2017).

Também ficou evidente na fala de Prof 4 que as atividades elaboradas na perspectiva das brincadeiras, a partir da interação entre as professoras e pesquisadores, com base nos conflitos sociais, apresentam-se como potenciais para promover uma formação cidadã, conscientizadora e transformadora (Delizoicov, Angotti e Pernambuco, 2011). Em contrapartida, o modelo educacional pautado em critérios convencionais de seleção de conteúdos, inviabiliza a tomada de decisóes no processo educativo (Rosa, 2019).

Outro aspecto a destacar na interação entre a Prof4 e o Pesq1, é uma aproximação dos processos de tomada de decisões, pois, a elaboração das atividades ocorre de forma participativa, valorizando a opinião de todos os sujeitos, e as decisóes são tomadas coletivamente, ou seja, por meio de um processo colaborativo e democrático, viabilizando a cultura de participação (Rosa, 2019). A fala de Prof3, ao referir-se "as brincadeiras foram criadas para conscientizar e pensar diferente", possibilita a abordagem de temas locais, de relevância social, como ponto de partida para o planejamento e elaboração das atividades que visam à emancipação de seus educandos, bem como novas relaçóes entre a sociedade e o conhecimento científico capaz de promover o conhecimento novo (Roso, Auler e Delizoicov, 2020). Pode-se afirmar que as atividades didático-pedagógicas, mencionadas por Prof4, foram realizadas de forma participativa, democrática e colaborativa entre os professores e integrantes do GEATEC, tendo em vista a promoção dos seus participantes, a inclusão social e a equidade social, na comunidade escolar, aproximando-se de um dos fundamentos da TS que é a tomada de decisóes, destacada por Roso (2017).

Além de evidenciar a importância de discutir a tomada de decisóes nos processos formativos/educativos e na elaboração de atividades didático-pedagógicas de Educação em Ciências, balizadas nos pressupostos político-pedagógicos freireanos e os fundamentos da TS, constatou-se a atribuição de valores democráticos na implementação dessas atividades, por parte das crianças, como explicita Cri1:

Não pode jogar o lixo no mangue e nem o esgoto no mangue, porque isso os peixinhos vão morrer, não vão sobreviver ir ir... vão achar que o lixo é pra comida e depois vão comer plástico e é muito nojento e aí... 
quando pega o lixo, ele tem que pegar e depois jogar o lixo lá no lixo, mais quando você fica sem lixo todo lago é bom e ai os peixes ficam vivos o dia todo, mas se jogar o lixo no mangue não ébom, porque assim não pode, assim como a praia não pode jogar lixo e nem o mangue, nem o rio que não pode jogar lixo. (Cri1).

No extrato da fala de Cri1 é possível perceber uma compreensão crítica das crianças com relação à importância de dar um destino correto aos dejetos domésticos e a conservação do meio ambiente local, ou seja, há indícios de tomada de decisóes acerca da realidade que ela está imersa. Isso revela que as atividades didático-pedagógicas desenvolvidas em uma proposta dialógica e problematizadora, podem contribuir para ampliar a visão das crianças sobre suas realidades e, com isso, "a leitura do mundo precede a leitura da palavra" (Freire, 1987, p. 11).

Outro fator a destacar, refere-se ao fato da fala de Cri1 apresentar elementos coerentes com as questóes valorativas, em especial, ao explicitar os cuidados que os demais moradores devem tomar com as questóes ambientais locais, as quais configuram-se como uma concepção contra-hegemônica no processo educativo, uma vez que a visão crítica potencializa a superação das demandas sociais (Silva, 2004) e socioambientais locais. Roso (2017) sinaliza que essas demandas podem ser superadas por meio de produçóes científico-tecnológicas contra-hegemônicas (Tecnologia e Sociedade), a exemplo da TS que está em coerência com a Adequação Sociotécnica, a qual, foi desenvolvida no contexto escolar.

A fala de Cri1 também apresenta algumas contradiçóes sociais, historicamente situadas na realidade da população do bairro Iguape e que podem ser utilizadas como ponto de partida para desenvolver a cultura de participação no espaço escolar, tendo em vista a participação ativa das crianças no espaço escolar, bem como a conscientização para a transformação local, por meio de um modelo de democratização em processos decisórios, tornando-os protagonistas sociais (Roso, Auler e Delizoicov, 2020).

Outro aspecto a destacar durante a atividade da Fossa Séptica Ecológica, refere-se à explicitação das crianças sobre alguns aspectos que envolvem a realidade em que vivem, como é possível observar no momento da problematização realizada pela professora Prof1:

- Tem um cano, ele sai do banheiro e o que sai desse cano? (Prof1)

- Pro rio /água/cocô/xixi. (Cri3)

- Para onde vão? (Prof1)

- Para o esgoto. (Cri2)

- Qual o é bichinho que gosta de ficar no lugar sujo e no esgoto, deixa eu ver se vocês já sabem?(Prof1)

- A barata! (Cri2)

- O Rato! (Cri1).

A interação entre Prof1 e as crianças possibilita relacionar a atividade da Fossa Séptica Ecológica com a realidade local. Além disso, percebe-se que as crianças associam a atividade da fossa às suas vivências, tanto sobre o destino dos dejetos domésticos quanto os animais que se encontram em ambientes poluídos, a exemplo das baratas e os ratos (pragas urbanas). Essa interação entre a Prof1 e as crianças indica uma relação dialógica, que possibilita a elas condiçóes viáveis para o desenvolvimento de uma consciência comunitária em sua formação. Ou seja, contribui para a concretização do Ser Mais (Freire, 1987) - da consciência de sua inconclusão, e que por meio de ações educativas societárias podem potencializar uma nova concepção de mundo e possibilitar uma transformação concreta em seu contexto social.

Outro fator a destacar, diz respeito à relação dialógica estabelecida entre a Prof1 e as crianças, atrelado a uma prática pedagógica emancipadora que está em coerência com a concepção educativa em face dos processos decisórios na aprendizagem coletiva, tendo em vista a valorização do conhecimento popular e/ou saberes prévios das crianças, como ponto de partida para a apropriação e democratização do conhecimento científico e (Auler, 2018). Roso, Auler e Delizoicov (2020) sinalizaram que processos decisórios no Ensino 
de Ciências ainda são incipientes, contudo esse processo foi evidenciado por meio da atividade didático-pedagógica sobre a Fossa Séptica Ecológica com as crianças, que possibilitou a tomada de decisôes em uma ação educativa colaborativa no Ensino de Ciências, uma vez que os Atores Sociais, por meio do diálogo e as suas participaçôes ativas, buscaram a superação de visões ingênuas no seu ambiente social, bem como a construção de uma consciência crítica, a partir de valores distintos dos hegemônicos.

Em síntese, as açôes realizadas pelas professoras, baseadas na TS, sinalizaram a autonomia delas quanto à tomada de decisões na organização do currículo e na implementação de atividades didático-pedagógicas, tendo como ponto de partida a realidade em que vivem as crianças.

\section{ALGUMAS CONSIDERAÇÕES E CONTRIBUIÇÕES PARA A EDUCAÇÃO EM CIÊNCIAS}

O processo formativo/educativo realizado com as professoras da Escola Padre Giuseppe Bonomi, baseado na TS e suas relaçôes com pressupostos freireanos, indicou o potencial no desenvolvimento de uma prática educativa societária enriquecida de valores democráticos, como a autonomia e a tomada de decisão que potencializaram a participação ativa dos Atores Sociais em todas as etapas da proposta pedagógica. Nesse sentido, o potencial da autonomia está relacionado a dois aspectos: a) autonomia dos professores frente à organização curricular prescritiva: que foi identificada na fala das professoras, ao expressarem que seria importante inserir problemas da comunidade nas atividades escolares, ou seja, apresentando um pensamento crítico sobre a organização e elaboração das atividades que envolveram conhecimentos das Ciências Naturais, os problemas sociais locais, indicando a superação do medo da liberdade (Alves e Silva, 2004); e b) autonomia das crianças no sentido do enfrentamento de problemas concretos presentes em sua realidade: isso ocorreu, por exemplo, quando as crianças relatam sobre o descarte irregular de dejetos domésticos no manguezal e no rio e suas possíveis consequências, evidenciando um pensamento crítico sobre a realidade em que vivem e um posicionamento autônomo e participativo.

A tomada de decisóes foi constatada nas professoras quando elas passaram a reorganizar o currículo escolar e implementar em sala de aula atividades que tomam como ponto de partida as contradiçóes sociais em que vivem as crianças. Por exemplo, uma das professoras realizou atividades na perspectiva das brincadeiras voltadas para os problemas concretos da comunidade escolar/local, como o descarte de dejetos domésticos no manguezal, na tentativa de promover a conscientização sobre a realidade que as crianças estão inseridas. As crianças, por sua vez, passam a ser capazes de tomar decisóes frente a questóes que fazem parte de suas vivências e chegam a apresentar alternativas para superar os conflitos locais, como medidas que evitam o descarte de resíduos domésticos nos manguezais.

Elementos da tomada de decisões potencializaram a compreensão da realidade na comunidade escolar e local, em especial, quando a Prof3 explicita que a elaboração das atividades de Ciências Naturais, como a réplica da Fossa Séptica Ecológica, na perspectiva da brincadeira, contribuiu para uma concepção crítica das crianças com relação aos dejetos domésticos despejados de forma irregular no seu meio social. Desta forma, os processos democráticos foram imprescindíveis para a discussão de questôes que permeiam a comunidade do Iguape, como os dejetos domésticos, pragas urbanas, degradação ambiental, entre outros, que também são passíveis de serem problematizados em sala de aula e, superados por meio do desenvolvimento de TS, em um processo colaborativo entre seus Atores sociais locais. Além disso, a tomada de decisóes potencializou uma concepção de educação crítica, dialógica e transformadora, sinalizando um caminho para a inserção das necessidades reais da comunidade escolar no âmbito educacional, ou seja, um direcionamento para a ressignificação do currículo de Educação em Ciências (Roso, Auler e Delizoicov, 2020).

Outro aspecto a destacar no planejamento e na implementação da atividade sobre a Fossa Séptica Ecológica foi a constituição de uma cultura de participação (Rosa, 2019), pois os sujeitos participantes apro- 
ximaram-se dos processos democráticos participativos orientados para uma práxis política transformadora na área da Educação em Ciências. A cultura de participação está relacionada à atuação dos professores, pesquisadores e as crianças no exercício ativo de cidadania, na promoção de novos valores, que sinalizam uma proposta dialógica, crítica e humanizadora (Roso e Auler, 2016).

Alguns aspectos que permeiam a concepção de TS, como as questôes valorativas e a inserção da Adequação Sociotécnica nos processos formativos/educativos e produtivos são capazes de potencializar uma educação humanizadora e emancipadora. Isso ficou explícito no planejamento e implementação da atividade didático-pedagógica da Fossa Séptica Ecológica que possibilitou a participação ativa do Atores Sociais direcionada por valores democráticos, como o diálogo, o respeito e a valorização às falas dos participantes. Também foi possível constatar que a relação da TS com a Educação em Ciências contribui na superação das produçóes científico-tecnológicas convencionais no âmbito da Educação Básica, uma vez que a proposta pedagógica da Fossa Séptica Ecológica desenvolvida na comunidade foi planejada e efetivada a partir de valores democráticos, protagonismo social, democratização do conhecimento científico e valorização do conhecimento popular. A efetivação ou reaplicação da Fossa Séptica Ecológica na comunidade escolar, no presente estudo, explicitou que é possível inserir discussões relacionadas à TS na Educação em Ciências e no currículo escolar, tendo em vista os processos formativos/educativos, a partir de novas concepçóes e novos valores sobre as demandas sociais, socioambientais e tecnológicas locais.

Compreende-se que para a construção de uma sociedade mais igualitária, democrática e participativa, é de fundamental importância que a escola desenvolva açôes educativas voltadas para a reorientação curricular, elaboração e efetivação de atividades didático-pedagógicas em uma perspectiva dialógica, problematizadora e humanizadora, capaz de potencializar a formação crítica e o protagonismo social nos seus Atores Sociais. Contudo, ainda há alguns aspectos da TS que necessitam ser melhor investigados e compreendidos, do ponto de vista da pesquisa em Educação em Ciências, na busca de uma educação emancipadora capaz de potencializar os Atores Sociais na compreensão do sujeito e o seu posicionamento diante de contradições sociais locais. Dentre as questôes da TS que necessitam ser melhor compreendidas, está a inserção dos Princípios - autonomia e tomada de decisões - e Ações - coaprendizagem e reaplicação - na formação inicial de professores de Ciências, bem como a articulação da TS à dinâmica da IT no contexto de Incubadoras Sociais, via extensão universitária, na tentativa de ampliar os processos científico-tecnológicos a partir da realidade local.

Por fim, chama-se atenção para o fato de que as demandas sociais e socioambientais, como a ausência de saneamento básico na comunidade do Iguape, apontam para a falta de uma reflexão crítica sobre o papel dos órgãos públicos competentes, bem como para a necessidade da construção de Políticas Públicas em Ciência e Tecnologia e Política Pública Ambiental, em que suas diretrizes e princípios norteadores estejam em coerência com os pressupostos da TS. Isso indica a necessidade de vincular as demandas sociais, socioambientais e sociotécnica em uma dimensão mais ampla (Thomas, 2009), a partir de política ambiental e tecnológica de caráter municipal ou estadual, na tentativa de potencializar os processos de Adequação Sociotécnica contribuindo com o protagonismo social.

\section{REFERÊNCIAS}

ARCHANJO, M. G. J.; GEHLEN, S. T. A Tecnologia Social e sua Contribuição para a Educação em Ciências. Revista Brasileira de Pesquisa em Educação em Ciências. V. 20, 345-374. Belo Horizonte, 2020. Doi: 10.28976/1984-2686rbpec2020u345374.

ARCHANJO, M. G. J. Tecnologia Social no contexto de uma comunidade escolar: limites e possiblidades para a Educação em Ciências. (Mestrado em Educação em Ciências) - Universidade Estadual de Santa Cruz, Ilhéus, 2019.

ASSUNÇÃO, J. L. A Abordagem Temática Freireana na elaboração de um Projeto Politico-Pedagógico configurado como práxis criadora. (Mestrado em Educação em Ciências) - Universidade Estadual de Santa Cruz, Ilhéus, 2019. 
ALVES, A. H. B., SILVA, A. F. G. Manifestações de Obstáculos Gnosiológicos para a Seleção de Conteúdos na Implementação de um Currículo Crítico em Ciências Naturais. Alexandria - Revista de Educação em Ciência e Tecnologia. v.8, n.1, p.181-207, 2015.

ASA, Articulação no Semi-Árido Brasileiro: construindo um futuro no semiárido brasileiro, 2011. Disponível em:www.asabrasil.org.br>acessado em: 08.07.2020. Acesso em :10 jul. 2020.

AULER, D. Cuidado! Um cavalo viciado tendo a voltar para o mesmo lugar. Curitiba: Appris, 2018.

AULER, D.; DELIZOICOV, D. Investigação de Temas CTS no contexto do Pensamento Latino-Americano. Linhas Criticas, v.25, n. 45, p. 275-296, 2015. Disponível em: https://doi.org/10.26512/lc.v21i45.4525.

BARBOSA, L. S. O Brincar no Contexto dos Três Momentos Pedagógicos: limites e possibilidades para Educação Infantil. (Mestrado em Educação em Ciências) Universidade Estadual de Santa Cruz, Ilhéus, 2020.

CENTA, F. G.; MUENCHEN, C. O Despertar para uma Cultura de Participação no Trabalho com um Tema Gerador. Alexandria - Revista de Educação em Ciência e Tecnologia, v.9, n.1, p.263-291, 2018. Disponível em: https://doi. org/10.5007/1982-5153.2016v9n1p263.

DAGNINO, R.; BRANDÃO, F. C.; NOVAES, H. T. Sobre o Marco Analitico-Conceitual da Tecnologia Social: uma estratégia para o desenvolvimento. 2a ed. Komedi. p.103-16. Rio de Janeiro, 2004.

DAGNINO, R. Tecnologia Social: contribuiçôes conceituais e metodológicas. Campina Grande, PB: Eduepb. Florianópolis, 2014.

DAGNINO, R. Como é a universidade de que o Brasil precisa? Avaliação, v.20, n.2, p. 293-333, 2015. http://dx.doi. org/10.590/S1414-40772015000200003.

DAGNINO, R. Tecnociência solidária: um manual estratégico. Lutas Anticapital, ed.1. Marília, 2019.

DELIZOICOV, D. Concepção problematizadora do ensino de ciências na educação formal: relato e análise de uma prática educacional na Guiné Bissau. Dissertação (Mestrado em Ensino de Ciências) Faculdade de Educação da Universidade de São Paulo, São Paulo, 1982.

DELIZOICOV, D. Conhecimento, tensôes e transiçôes. Tese (Doutorado em Educação). Faculdade de Educação da Universidade de São Paulo. São Paulo, 1991.

DELIZOICOV, D.; ANGOTTI, J. A.; PERNAMBUCO, M. M. Ensino de Ciências: Fundamentos e Métodos. São Paulo: Cortez, 2011.

FILHO, F. F. L., GOERCK, C., GAVIRAGHI, F., RAMOS, S. S. Incubadora Social da UFSM: incubação e identidade de empreendimentos econômicos solidários. $33^{\circ}$ Seminário de extensão Universidade da Região Sul - UNIPAMPA. Bagé-RS, 2015.

FREIRE, P. Pedagogia do Oprimido. 17aㅡ ed. Rio de Janeiro: Paz e Terra, 1987.

FREIRE, Paulo. A Importância do Ato de Ler- em três artigos que se completam. 43a ed. São Paulo: Cortez, 2002.

FREIRE, P. Extensão ou Comunicação?. 7a ed. Paz e Terra, v.1. Rio de Janeiro, 1983.

GARRIDO, A. C., SANGIOGO, F. A. Etapas e Momentos da Investigação Temática Freireana no Contexto da Escola da Colônia de Pescadores Z-3. Revista Humanidade e Inovação, v.7, n. 7, 2020. Disponível em: https://revista.unitins. br/index .php/humanidadeseinovacao/article/view/2652. Acesso em: 10 jul. 2020.

LOUREIRO, C. F. B.; TORRES, J. R. Educação Ambiental: dialogando com Paulo Freire. 1ª ed. Cortez. São Paulo 2014.

LASSANCE, A. E. JR; PEDREIRA, J. S. Tecnologias sociais e politicas públicas. Núcleo Pesq. em Políticas Públicas (NP3) -. Universidade de Brasília, Brasília, 2004.

MAgOGA, T. F., MUENCHEN, C. A Abordagem Temática Caracterizada por Pesquisadores da Área de Ensino de Ciências. Revista Brasileira de Pesquisa em Educação em Ciências, v.20, p.315-343, 2020. Disponível em: https:// doi.org/10.28976/1984-2686rbpec2020u315343. 
MILLI, J. C. L.; ALMEIDA, E. S., GEHLEN, S. T. A Rede Temática e o Ciclo Temático na busca pela Cultura de Participação na Educação CTS. Alexandria. Revista em Educação em Ciência e Tecnologia, Florianópolis, 2018.

MORAES, R.; GALIAZZI, M. C. Análise Textual Discursiva. 2ª ed. UNIJUÍ, 2011.

ROSA, S. E. Educação CTS: contribuições para a constituição de culturas de participação. Tese (Doutorado em Educação em Ciências) Universidade de Brasília, Brasília, 2019.

ROSO, C. C. Transformaçôes na Educação CTS: uma proposta a partir do conceito de Tecnologia Social. Tese (Doutorado em Educação em Ciências), Universidade Federal de Santa Catarina, PPGECT, Florianópolis, 2017.

ROSO, C. C.; AULER, D. A participação na construção do currículo: práticas educativas vinculadas ao movimento CTS. Ciências छ̊ Educação, v. 22, n. 2, pp. 371-389 - Bauru, 2016. Disponível em: http://dx.doi.org/10.1590/1516731320160020007.

ROSO, C. C.; DELIZOICOV, D. Transformaçốes na Educação CTS: elementos a partir do conceito de Tecnologia Social. XII Encontro Nacional de Pesquisa em Educação em Ciências. Universidade Federal do Rio Grande do Norte, Natal, 2019.

SAMAGAIA, R.R. Comunicação, divulgação e educação científica: Uma análise em função dos modelos teóricos e pedagógicos. Tese (Doutorado em Educação em Ciências). Universidade Federal de Santa Catarina, PPGECT, Florianópolis, 2016.

SANTOS, J. S., LIMA, J. A., BARBOSA, L. dos S., GEHLEN, S. T. A dimensão Axiológica na elaboração de uma Rede Temática na Educação Infantil: contribuições para o Ensino de Ciências. Revista Brasileira de Pesquisa em Educação em Ciências, 19, 649-682, 2019. https://doi.org/10.28976/1984-2686rbpec2019u649682

SANTOS, J. S. A Dimensão Axiológica no Desenvolvimento e Implementação de Atividades Didático-Pedagógicas Via Tema Gerador. (Mestrado em Educação em Ciências) - Universidade Estadual de Santa Cruz, Ilhéus, 2020.

SILVA, A. F. G. A construção do currículo na perspectiva popular crítica: das falas significativas às práticas contextualizadas. Tese (Doutorado em Educação). Pontifícia Universidade Católica de São Paulo, São Paulo, 2004.

THOMAS, H. Tecnologias para inclusão social e politicas públicas na América Latina. In: OTTERLOO, A. e ALBUQUERQUE, L. C. Tecnologias sociais: Caminhos para a sustentabilidade. Brasília: Rede de Tecnologia Social, p. 25-82, Brasília, 2009.

\section{NOTAS}

1 Este artigo é parte de algumas discussões realizadas na dissertação de mestrado de Archanjo (2019). Apoio financeiro CNPq e CAPES.

2 Reitera-se que o presente trabalho é parte da dissertação de mestrado Archanjo (2019) defendida antes da discussão sobre a Tecnociência Solidária, apresentada por Dagnino (2019). Em trabalhos futuros será adotada a expressão Tecnociência Solidária, uma vez que seus princípios estão coerentes com a proposta pedagógica aqui defendida, pautada nos pressupostos teórico-metodológicos de Paulo Freire.

3 Site do grupo: https://geatecuesc8.wixsite.com/geatec

4 Esse processo formativo deu continuidade ao Estudo Assunção (2019) que teve como foco a elaboração do Projeto Político Pedagógico da Escola Padre Giuseppe Bonomi. Outros trabalhos também foram desenvolvidos a partir deste estudo, como: Barbosa (2020), que planejou, elaborou e implementou as atividades com as crianças por meio das brincadeiras, seguindo os 3MP, e Santos (2020) que discutiu os valores a partir das brincadeiras, em uma dimensão axiológica.

5 O estudo de Santos et al. (2019) discute com mais detalhes a elaboração coletiva desta RT, no contexto desse processo formativo desenvolvido na escola Padre Giuseppe Bonomi, e destaca a compreensão de algumas professoras acerca dos valores presentes na construção desta RT.

6 Aprovado pelo Comitê de Ética e Pesquisa em Seres Humanos. 
7 A maquete foi construída pelas professoras em conjunto com os integrantes do GEATEC.

8 A Fossa Séptica Ecológica foi confeccionada com materiais reutilizáveis, com objetivo de contextualizar os conhecimentos de forma sistematizados sobre os problemas locais da comunidade do Iguape.

9 O medo da liberdade é configurado quando o professor perde a autonomia em sala de aula, impedindo que esse tenha uma visão crítica com relação ao modelo educacional tradicional que está inserido, culminando na dicotomia entre a teoria e prática docente, uma vez que as demandas sociais não são problematizadas (Alves e Silva, 2015).

\section{Miguel Guilhermino de Archanjo Junior}

Doutorando em Educação Científica e Formação de Professores

Programa de Pós-Graduação Educação Científica e Formação de Professores

Integrante do Grupo de Estudo e Pesquisa sobre Abordagem Temática no Ensino de Ciências (GEATEC/UESC)

Universidade Estadual do Sudoeste da Bahia - Jequié, Bahia, Brasil.

E-mail:miguel85archanjo@gmail.com

\section{Simoni Tormohlen Gehlen}

Doutora em Educação Científica e Tecnológica pela Universidade Federal de Santa Catarina (UFSC)

Professora do Departamento de Ciências Exatas e Tecnológicas e do Programa de Pós-Graduação em Educação em Ciências da Universidade Estadual de Santa Cruz (UESC), Ihéus/BA.

Coordenadora do Grupo de Estudo e Pesquisa sobre Abordagem Temática no Ensino de Ciências (GEATEC/UESC)

E-mail: stgehlen@uesc.br

\section{Contato:}

Miguel Guilhermino de Archanjo Junior

Universidade Estadual do Sudoeste da Bahia

Programa de Pós-Graduação Educação Científica e Formação de Professores

Av. José Moreira Sobrinho, s/n - Jequiezinho

Jequié - BA | Brasil

CEP 45.205-490

Editor responsável:

Geide Rosa Coelho 